\title{
A summary of MSc research on school libraries in the UK
}

\author{
Cristina Sacco Ritchie
}

\begin{abstract}
This paper summarises the author's MSc dissertation which was a co-winner of the 2009 LIRG student prize. It comprises two parts. The first part, a survey of school library salaries, was published in the May 2009 issue of Library and Information Update. This survey used Freedom of Information Act requests to obtain the pay grades and salaries of school librarians and public librarians across local authorities in Scotland. The second part of the dissertation discusses the findings of research conducted on the self-perceived status of secondary school librarians in the UK, with a focus on Scotland. This research will be published in a forthcoming issue of the Journal of Librarianship and Information Science.
\end{abstract}

\section{Part one: Librarians' salaries}

Two sets of Freedom of Information Act (FOI) Requests were sent to councils across Scotland, one asking for salary information of school librarians, and one asking for salary information of public librarians. Results indicate that there is a very wide variation in the salaries of school librarians from council to council, and most school librarians in Scotland (two-thirds) have their salaries capped at $£ 24,000$ per year. In addition, there is also a lack of consistency regarding the relative salary of public librarians and school librarians. In many councils, public librarians have both higher salary minimums and maximums than school librarians, though in some, public librarians only enjoy a higher maximum, and there are many more variations as well. In addition, the results indicate that local authorities in Scotland maintain a policy of hiring librarians rather than library assistants to staff school libraries, with the exception of two responding councils (31 out of 32 councils responded to the school library survey, which was issued separately from the public library salary survey).

\section{Cristina Sacco Ritchie}

Cristina is a $\mathrm{PhD}$ researcher at the University of Strathclyde, Department of Computer and Information Science, Glasgow

Email: cristina.ritchie@cis.strath.ac.uk

Received 26 February 2010

Accepted 10 March 2010 


\section{Part two: Self perceived status of librarians}

The aim of the second part of the research project was to ascertain how school librarians perceive their status within the school by looking at their perceptions of: their relationships with their colleagues and supervisors, their role within the school, job satisfaction, and views on their careers and their training. This research originated from some negative perceptions about school librarianship, observed in a small group of school librarians met by the researcher during a work placement. One goal of the research is to investigate to what degree school librarians across Scotland and indeed, the UK, share these perceptions. The negative perceptions about school librarianship observed include:

- that school librarians hold the lowest status of all types of librarians;

- that school librarianship is a temporary post that one should escape or else risk "getting stuck";

- that school librarians are respected less than other librarians;

- that the success of the library depends entirely on the personality of the librarian; and

- that senior management largely do not understand or value the school library.

Many of these perceptions paint a rather negative picture of school librarianship. These perceptions were held consistently across different sites within the same council, however, little academic research is available on the perceptions of school librarians for comparison. The hypotheses for this project, therefore, are:

- school librarians are dissatisfied with their jobs;

- school librarians feel they are stuck in their positions until retirement;

- if given the chance, most school librarians would choose a different career;

- school librarians do not feel respected by their supervisors;

- school librarians are isolated from their school communities and from the library community as a whole;

The methods used comprised a review of current and historical literature and a UK-wide survey in the form of a questionnaire, which was distributed electronically. The survey questions covered topics including job satisfaction, relationships within the school, training, professional support, and career goals. Recent research into UK school libraries is scant, and therefore a broad range of questions was necessary in order to best identify potential influencers of one's self-perceived status. The survey asked school librarians to compare their own perceived status in the school to job levels including "clerical staff", "teacher" and "head of department", and asked respondents whether they felt that teachers and their supervisors treated them as important and professional members of staff. The survey asked respondents about their training and qualifications, and asked them to comment on their experiences in the role, which generated over 100 thoughtful and, at times lengthy, responses. A very brief summary follows. 
Most respondents reported levels of self-perceived status on par with heads of department, along with many other positive feelings toward their jobs. These respondents fit the following profile: they believe that teachers and their supervisors support the library, they always felt welcome in the staff rooms, they feel regarded as both an important and a professional member of staff, and they are satisfied with their jobs. They also believe that they are respected as much as other types of librarians and feel like members of both the school and the library communities. This is a very positive picture of school librarianship, however there are those whose working lives are not so fulfilled.

Those who identify themselves as having a low status within the school are less likely to offer workshops for teachers, are more likely to report that school librarians as a whole are respected less than other librarians, are less likely to feel supported by management and colleagues, and are less likely to feel regarded as important or professional members of staff. They are also less likely to be satisfied in their jobs. Of the respondents who ranked themselves as having an equal status to clerical staff, only 50\% report holding a CILIP-accredited qualification (compared to $78 \%$ of all respondents), so half of those who do not feel regarded as a professional member of school staff are not actually professional librarians. Does this mean that having a professional qualification improves one's status within the school? Certainly, at least, the data suggest a link between not having a professional qualification and not feeling as if one is perceived as a professional.

Survey responses indicate that support from management seems to be the element most closely-linked with the self-perceived status of school librarians, and it seems particularly relevant in its absence. Lack of support from management sets an example for teachers to follow, and determines which aspects of the school are to be treated as important. With the current trend of private-sector policies creeping into public-sector bodies, school librarians may find their positions jeopardized if their value is not made known. Is there a way to improve the position of school librarians? In the US, the American Library Association (ALA) has lobbied for years for tougher qualification requirements and for the importance of having a qualified school librarian in every school. It would follow logically, therefore, that CILIP is in the best position to do this for school librarians in the UK. As the national representative professional organization for librarians, on what other shoulders could this responsibility fall?

A full version of this article will appear in a forthcoming issue of the Journal of Librarianship and Information Science, to which CILIP members have access via http://www.cilip.org.uk/membership/benefits/informed/onlinedatabases/pages/sage.aspx 


\section{Open access and copyright}

Library and Information Research is an open access journal. A freely available copy of this paper may be downloaded from the journal's website:

http://www.cilipjournals.org.uk/lir

Copyright and associated moral rights in works published in Library and Information Research are retained by the author(s) but this paper may be used freely, with proper attribution, in educational and other non-commercial settings. 